patients and controls. We have used these same study procedures for matched case-control studies of other birth defects (anencephaly (66 pairs); spina bifida (135 pairs); Down's syndrome (103 pairs); hypospadias (99 pairs)). Neither in the total group of 403 pairs, nor in any of the subgroups, did we find a significant or substantial increase in the number of patients exposed to hormones. This suggests that our study procedures do not produce results that are biased toward detecting hormone exposures among patients. Our study is not large in terms of number of cases, so that the results should be interpreted cautiously because the confidence limits on the relative risks tend to be wide. Our point estimate on relative risk of exposure is 8.5 and it is statistically significant, but it would be prudent to await the results of other studies before finally judging the actual relative risk value. Finally, our results suggest that other studies that include a greater proportion of less severe cases of CHD should find lower relative risk estimates than we have found. But this difference should not affect the attributable risk estimates for severe CHD among live births.

Inadvertent exposure to oral contraceptives during pregnancy represented the smallest proportion of exposures in the group we studied ( 2 out of 18). Both of these infants were boys and both died within the first week of life. In judging the riskbenefit of each of the three types of hormone exposure the small risk associated with inadvertent exposure through oral contraceptives seems negligible in comparison with the large-scale benefits from effective contraception. Hormone pregnancy tests were the most common type of exposure (10 out of 18). These represent needless exposures and their continued use is not justified because other types of pregnancy tests are available.
The risk benefit of supportive hormone treatment cannot be evaluated from any existing data. If the weight of clinical judgement still favours a possible benefit from supportive hormone treatment during pregnancy then a controlled clinical trial should certainly be conducted to determine whether the benefit outweighs the risk.

We thank Dr Margaret Hoff and the staff of the Office of Biostatistics, New York State Department of Health, for their help in analysing the data. This research was supported by Contract NO 2 HD 52802, National Institute of Child Health and Human Development.

\section{References}

${ }^{1}$ Levy, E P, Cohen, A, and Frazer, F C, Lancet, 1973, 1, 611.

2 Nora, J J, and Nora, A H, Lancet, 1973, 1, 941.

3 Janerich, D T, Piper, J M, and Glebatis, D M, New England Fournal of Medicine, 1974, 291, 697.

${ }^{4}$ Harlap, S, Prywes, R, and Davies, A M, Lancet, 1975, 1, 682.

5 Greenberg, G, et al, British Medical fournal, 1975, 2, 191.

- Nora, A H, and Nora, J J, Archives of Environmental Health, 1975, 30, 17.

Lancet, 1975, 2, 692.

${ }^{8}$ Janerich, D T, Flink, E M, and Keogh, M, British fournal of Obstetrics and Gynaecology, 1976, 83, 617.

${ }^{9}$ Mulvihill, J J, Mulvihill, C G, and Neill, C A, Teratology, 1974, 9, A30.

10 Hook, E B, et al, Teratology, 1974, 9, A21.

1 Yasuda, M, and Miller, J R, Teratology, 1975, 12, 239.

12 MacMahon, B, McKeown, T, and Record, R G, British Heart Fournal, $1953,15,121$.

(Accepted 17 February 1977)

\title{
Nicotine chewing gum as a substitute for smoking
}

\author{
M A H RUSSELL, S R SUTTON, C FEYERABEND, P V COLE, Y SALOOJEE
}

British Medical fournal, 1977, 1, 1060-1063

\section{Summary}

The capacity of nicotine-containing chewing gum to produce plasma nicotine levels comparable to heavy cigarette smoking was tested in 21 subjects. On a fixed schedule of one piece of gum ( $4 \mathrm{mg}$ nicotine) per hour, the average peak plasma nicotine concentration was 175.7 $\mathrm{nmol} / \mathrm{l}(28.5 \mathrm{ng} / \mathrm{ml})$ compared to $189.3 \mathrm{nmol} / 1(30.7 \mathrm{ng} / \mathrm{ml})$ obtained from normal ad libitum smoking. Unpleasant side effects were common and in some cases plasma nicotine concentrations were two and even three times as high as with smoking. The chewing gum provided some satisfaction to all but four subjects, but its degree was not

Addiction Research Unit, Institute of Psychiatry, London SE5 8AF M A H RUSSELL, MRCP, MRCPSYCH, senior lecturer and honorary consultant psychiatrist

S R SUTTON, BA, MSC, research worker

Poisons Unit, New Cross Hospital, London SE14 5BH

C FEYERABEND, BSC, research worker

Anaesthetic Research Laboratory, St Bartholomew's Hospital, London EC1A 7BE

P V COLE, MB, FFARCS, consultant anaesthetist

Y SALOOJEE, MIBIOL, research worker related to the concentration of plasma nicotine it produced, neither was there an inverse relation between the plasma nicotine concentration while taking the gum and the subjective sense of missing cigarettes. This suggests that the capacity of the gum to act as a substitute for smoking is not necessarily related to its capacity to provide nicotine. Flexible dosage dictated by individual needs would probably lower the incidence of side effects and might secure closer approximation to smoking concentrations of plasma nicotine.

\section{Introduction}

The development of nicotine chewing gum as an aid to cigarette withdrawal ${ }^{1-5}$ is based on two assumptions. Firstly, that nicotine intake is an important component of dependence on smoking, and secondly that absorption of nicotine from chewing gum is sufficient to reproduce whatever positive pharmacological effects the smoker seeks to obtain, or to prevent whatever negative nicotine withdrawal effects he smokes to relieve or avoid. Neither assumption is yet unequivocally established, though much circumstantial evidence points to the importance of nicotine for most smokers. ${ }^{6}$

In assessing the potential clinical usefulness of nicotine chewing gum it would seem essential firstly to show that it can produce plasma nicotine concentrations comparable to those obtained from cigarette smoking. It has been available in two strengths, with $2 \mathrm{mg}$ or $4 \mathrm{mg}$ nicotine in each piece of gum. Owing to its local irritancy and lack of palatability we found that 
few smokers could tolerate the 4-mg gum. On the other hand, plasma nicatine concentrations produced by the 2-mg gum averaged only $66.0 \mathrm{nmol} / 1(10.7 \mathrm{ng} / \mathrm{ml})$ compared to 169.0 $\mathrm{nmol} / \mathrm{l}(27.4 \mathrm{ng} / \mathrm{ml})$ after smoking. ${ }^{4} \mathrm{~A}$ form of the gum has been developed recently, however, which is claimed by the manufacturers (A B Leo, Helsingborg, Sweden) to be more palatable and to be tolerated at the 4-mg strength. In a single subject, nicotine dosage of $4 \mathrm{mg}$ hourly taken in the form of this chewing gum produced plasma nicotine levels comparable to those from cigarette smoking at the rate of one cigarette (yielding $1.2 \mathrm{mg}$ nicotine) per hour. ${ }^{3}$

We report here an assessment of the acceptability of the stronger 4-mg nicotine gum in a larger sample of smokers and a comparison of the plasma nicotine concentrations produced when it is taken on a fixed schedule of one piece per hour with those obtained from normal ad libitum smoking.

\section{Subjects and methods}

Thirty-two cigarette smokers volunteered to take part in an "investigation to compare blood nicotine concentrations after smoking, and after chewing nicotine gum." Seven dropped out after the first session but only one appeared to do so because of dislike of the gum. In four others blood samples were lost due to breakage of specimen tubes. This report is confined to the 21 subjects for whom data were complete. We had hoped to obtain roughly equal numbers of men and women as well as heavy and light smokers, but there were only four men in the final sample of 21 and only two subjects smoked fewer than 20 cigarettes a day.

The subjects attended on two occasions: firstly (day 1) on a day of normal smoking, and secondly (day 2) on a day when they were taking nicotine chewing gum and not smoking. On day 1 they were instructed to smoke normally up to the time of their attendance. On arrival they were asked to smoke a cigarette, and venous blood samples were then taken at two minutes (for peak concentration) and 25 minutes ("trough" concentration) after the cigarette was completed. On day 2 , which was exactly a week later, they were instructed to stop smoking from the preceding midnight and to start the 4-mg nicotine gum soon after waking in the morning, taking it at a rate of one piece per hour, each chewed for at least 30 minutes. They arrived at the clinic shortly before a piece of gum was due so that the first blood sample (trough concentration) could be conveniently timed at roughly 30 minutes after completing a piece of gum - that is, one hour after starting it. They then started chewing another piece and the second blood sample (peak concentration) was taken 25 minutes later while they were still chewing.

On average $91 \%$ of the nicotine in the gum is released after 30 minutes of chewing. ${ }^{1}$ The peak plasma concentration is sometimes reached within 15 minutes, however, ${ }^{3}$ so we chose an interval of 25 minutes for sampling the plasma nicotine peaks. We ensured so far as possible that the subjects' activities were similar on the two attendance days. To minimise possible effects of lunch the subjects attended either before lunch (between 1200 and 1330) or later in the afternoon (1600 and 1800), whichever was the more convenient, but the time of day of each attendance was roughly the same for any one person. During the few days before the second attendance subjects were asked to practise chewing the gum two or three times a day so that they were not complete novices on the day of the full gum-chewing schedule. Urinary $\mathrm{pH}$ was not controlled.

Cigarette consumption and the time of starting and discarding each piece of gum were recorded on special cards. Blood samples were analysed for carboxyhaemoglobin (COHb) using an IL $182 \mathrm{CO}-$ oximeter $^{7}$ and plasma nicotine concentrations measured by gas chromatography. ${ }^{\times}$The laboratory workers were unaware of the design of the study. Linear analogue scales were used to obtain subjective ratings of the gum for "strength," "satisfaction," "taste evaluation," and the degree to which cigarettes were missed. We have found the test-retest reliability of such ratings to be satisfactory $(r=0.91) .{ }^{9} \mathrm{We}$ assessed the statistical significance of the findings using $t$ tests and product-moment correlations, but they were checked by nonparametric tests-Mann-Whitney $U$ test and rank order correlations.

\section{Results}

\section{PLASMA NICOTINE CONCENTRATIONS}

The results are shown in table I. Peak plasma nicotine concentrations produced by the nicotine chewing gum averaged $162 \cdot 1 \mathrm{nmol} / 1$ $(26.3 \mathrm{ng} / \mathrm{ml})$ and were not significantly different from the average of $194.2 \mathrm{nmol} / 1(31.5 \mathrm{ng} / \mathrm{ml})$ obtained from smoking cigarettes $(t=1 \cdot 1$; $\mathrm{DF}=20$; NS). Three subjects failed to chew the gum as instructed. Two of them (Nos 19 and 20) chewed each piece for only six minutes because of nausea and indigestion. The third (No 18), who had dentures, failed to renew the gum hourly and chewed each piece for an average of $78 \mathrm{~min}$. Excluding these three subjects the average peak plasma nicotine concentration produced by the chewing gum was very close to that obtained from smoking $-175 \cdot 7 \pm \mathrm{SD} 106.0 \mathrm{nmol} / 1$ $(28.5 \pm 17 \cdot 2 \mathrm{ng} / \mathrm{ml})$ and $189.3 \pm 74.0 \mathrm{nmol} / 1(30.7 \pm 12.0 \mathrm{ng} / \mathrm{ml})$, respectively.

Trough concentrations of plasma nicotine when taking the gum were slightly lower than when smoking, $116.5 \mathrm{nmol} / 1(18.9 \mathrm{ng} / \mathrm{ml})$ and

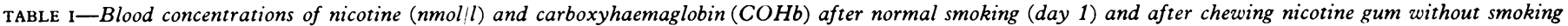
(day 2). Peak and trough concentrations were measured at 2 min and 25 min after smoking, and at 25 and 60 min after starting to chew nicotine gum

\begin{tabular}{|c|c|c|c|c|c|c|c|c|c|c|c|c|}
\hline \multirow{2}{*}{$\begin{array}{l}\text { Subject } \\
\text { No }\end{array}$} & \multirow{2}{*}{$\begin{array}{c}\text { Age } \\
(y r s) \\
\text { and sex }\end{array}$} & \multirow{2}{*}{$\underset{(\mathrm{kg})}{\text { Weight }}$} & \multicolumn{2}{|c|}{$\begin{array}{c}\text { Cigarette } \\
\text { consumption/day }\end{array}$} & \multicolumn{2}{|c|}{$\begin{array}{l}\text { Gum consumption } \\
(\text { day } 2)\end{array}$} & \multicolumn{3}{|c|}{$\begin{array}{l}\text { Blood concentrations } \\
\text { when smoking } \\
\text { (day 1) }\end{array}$} & \multicolumn{3}{|c|}{$\begin{array}{l}\text { Blood concentrations on 4-mg } \\
\text { nicotine gum without smoking } \\
\text { (day 2) }\end{array}$} \\
\hline & & & $\begin{array}{l}\text { Usual } \\
\text { No }\end{array}$ & Day 1 & $\begin{array}{l}\text { No of } \\
\text { pieces }\end{array}$ & $\begin{array}{c}\text { Mean } \\
\text { chewing time } \\
(\mathrm{min})\end{array}$ & Peak & Trough & $\underset{\left({ }^{\prime \prime}(1)\right.}{\mathrm{COHb}}$ & Peak & Trough & $\underset{\left({ }_{0}^{\circ}\right)}{\mathrm{COHb}}$ \\
\hline $\begin{array}{l}1^{*} \\
2 \\
3 \\
4^{*} \\
5 \\
6^{*} \\
7 \\
8 \\
9^{*} \\
10^{*} \\
11^{*} \\
12 \\
13^{*} \\
14 \\
15 \\
16 \\
17^{*} \\
18^{*+} \\
19^{+} \\
20^{+} \\
21\end{array}$ & $\begin{array}{l}33 \mathrm{M} \\
55 \mathrm{~F} \\
21 \mathrm{~F} \\
44 \mathrm{M} \\
27 \mathrm{~F} \\
33 \mathrm{~F} \\
24 \mathrm{~F} \\
38 \mathrm{~F} \\
44 \mathrm{~F} \\
37 \mathrm{M} \\
23 \mathrm{~F} \\
60 \mathrm{~F} \\
50 \mathrm{~F} \\
23 \mathrm{~F} \\
34 \mathrm{~F} \\
43 \mathrm{~F} \\
22 \mathrm{~F} \\
26 \mathrm{~F} \\
38 \mathrm{~F} \\
41 \mathrm{~F} \\
36 \mathrm{M}\end{array}$ & $\begin{array}{l}65 \cdot 8 \\
61 \cdot 0 \\
58 \cdot 5 \\
58 \cdot 1 \\
67 \cdot 0 \\
46 \cdot 3 \\
55 \cdot 0 \\
54 \cdot 4 \\
53 \cdot 1 \\
70 \cdot 0 \\
54 \cdot 4 \\
73 \cdot 5 \\
60 \cdot 3 \\
63 \cdot 5 \\
40 \cdot 4 \\
50 \cdot 8 \\
55 \cdot 0 \\
58 \cdot 5 \\
67 \cdot 0 \\
72 \cdot 1 \\
96 \cdot 6\end{array}$ & $\begin{array}{l}45 \\
25 \\
25 \\
15 \\
35 \\
35 \\
18 \\
43 \\
25 \\
60 \\
28 \\
25 \\
20 \\
30 \\
28 \\
30 \\
40 \\
35 \\
38 \\
55 \\
40\end{array}$ & $\begin{array}{r}27 \\
15 \\
8 \\
8 \\
9 \\
16 \\
4 \\
16 \\
12 \\
11 \\
14 \\
6 \\
11 \\
11 \\
8 \\
5 \\
27 \\
25 \\
8 \\
9 \\
14\end{array}$ & $\begin{array}{l}9 \\
4 \\
4 \\
7 \\
5 \\
8 \\
5 \\
5 \\
9 \\
3 \\
7 \\
5 \\
9 \\
5 \\
3 \\
5 \\
8 \\
6 \\
5 \\
5 \\
5\end{array}$ & $\begin{array}{r}30 \\
30 \\
30 \\
37 \\
33 \\
34 \\
33 \\
27 \\
31 \\
34 \\
29 \\
40 \\
30 \\
27 \\
42 \\
30 \\
27 \\
78 \\
6 \\
6 \\
31\end{array}$ & $\begin{array}{r}72 \cdot 7 \\
89 \cdot 4 \\
153 \cdot 4 \\
130 \cdot 7 \\
164 \cdot 0 \\
217 \cdot 6 \\
166.5 \\
163.4 \\
276.8 \\
185 \cdot 0 \\
215 \cdot 2 \\
284 \cdot 0 \\
134.4 \\
162.1 \\
232 \cdot 4 \\
153 \cdot 5 \\
381 \cdot 6 \\
326.1 \\
219 \cdot 5 \\
119 \cdot 6 \\
227.0\end{array}$ & $\begin{array}{r}73.4 \\
81.4 \\
96.2 \\
128.2 \\
137.0 \\
215.2 \\
170.0 \\
112.2 \\
186.8 \\
182.0 \\
216.4 \\
237.4 \\
122.1 \\
123.0 \\
163.0 \\
175.7 \\
201.6 \\
262.6 \\
158.4 \\
93.7 \\
126.4\end{array}$ & $\begin{array}{r}6 \cdot 2 \\
5 \cdot 4 \\
7 \cdot 0 \\
3 \cdot 3 \\
10 \cdot 2 \\
13 \cdot 3 \\
6 \cdot 3 \\
6 \cdot 9 \\
9 \cdot 0 \\
6 \cdot 5 \\
8 \cdot 1 \\
7 \cdot 1 \\
8 \cdot 9 \\
9 \cdot 9 \\
8 \cdot 7 \\
7 \cdot 7 \\
11 \cdot 1 \\
14 \cdot 4 \\
8 \cdot 6 \\
8 \cdot 3 \\
4 \cdot 7\end{array}$ & $\begin{array}{r}215 \cdot 2 \\
205 \cdot 3 \\
142.0 \\
156 \cdot 0 \\
184 \cdot 3 \\
366.0 \\
500 \cdot 0 \\
101 \cdot 1 \\
143.6 \\
140.0 \\
174.5 \\
219.0 \\
79.5 \\
71 \cdot 0 \\
105.4 \\
98.0 \\
151.0 \\
85.0 \\
120.8 \\
38.8 \\
108.0\end{array}$ & $\begin{array}{r}201 \cdot 0 \\
159 \cdot 1 \\
141 \cdot 0 \\
172 \cdot 0 \\
149 \cdot 0 \\
201 \cdot 6 \\
142 \cdot 4 \\
90 \cdot 6 \\
144 \cdot 3 \\
133 \cdot 0 \\
145 \cdot 0 \\
159 \cdot 0 \\
81 \cdot 0 \\
79 \cdot 5 \\
90 \cdot 0 \\
92 \cdot 0 \\
98 \cdot 0 \\
104 \cdot 8 \\
33 \cdot 0 \\
18.5 \\
17 \cdot 3\end{array}$ & $\begin{array}{l}0 \cdot 8 \\
1 \cdot 3 \\
2 \cdot 4 \\
2 \cdot 4 \\
1 \cdot 3 \\
0 \cdot 3 \\
0 \cdot 5 \\
2 \cdot 0 \\
1 \cdot 1 \\
2 \cdot 6 \\
1 \cdot 2 \\
1 \cdot 4 \\
3 \cdot 6 \\
2 \cdot 3 \\
3 \cdot 3 \\
3 \cdot 6 \\
1 \cdot 2 \\
2 \cdot 3 \\
0 \cdot 6 \\
1 \cdot 8 \\
2 \cdot 2\end{array}$ \\
\hline $\begin{array}{l}\text { Mean } \\
\text { ISD }\end{array}$ & $\begin{array}{l}35 \cdot 8 \\
11 \cdot 1\end{array}$ & $\begin{array}{l}61 \cdot 0 \\
11 \cdot 7\end{array}$ & $\begin{array}{l}33 \cdot 1 \\
11 \cdot 5\end{array}$ & $\begin{array}{r}12 \cdot 6 \\
6 \cdot 7\end{array}$ & $\begin{array}{l}5 \cdot 8 \\
1.9\end{array}$ & $\begin{array}{l}31 \cdot 7 \\
13 \cdot 8\end{array}$ & $\begin{array}{r}194 \cdot 2 \\
76 \cdot 5\end{array}$ & $\begin{array}{r}155 \cdot 4 \\
52 \cdot 4\end{array}$ & $\begin{array}{l}8 \cdot 2 \\
2 \cdot 7\end{array}$ & $\begin{array}{l}162 \cdot 1 \\
104 \cdot 2\end{array}$ & $\begin{array}{r}116.5 \\
53 \cdot 0\end{array}$ & $\begin{array}{l}1 \cdot 8 \\
1 \cdot 0\end{array}$ \\
\hline
\end{tabular}

* Subjects who attended after 1600 hours as opposed to between 1200 and 1330 hours.

†Subjects who failed to take gum as instructed. COHb concentrations are mean of two values coinciding with nicotine peak and trough concentrations.

Conversion: SI to traditional units-Plasma nicotine $1 \mathrm{nmol} / 1 \approx 0 \cdot 16 \mathrm{ng} / \mathrm{ml}$. 
$155.4 \mathrm{nmol} / 1(25.2 \mathrm{ng} / \mathrm{ml})$ respectively $(t=2.6 ; \mathrm{DF}=20 ; \mathrm{P}<0.02)$, but the difference is no longer significant when the three subjects who did not take the gum adequately are excluded $(127.6 \pm \mathrm{SD} 47.5 \mathrm{nmol} / 1$ $(20 \cdot 7 \pm 7 \cdot 7 \mathrm{ng} / \mathrm{ml})) v(152 \cdot 9 \pm 48 \cdot 7 \mathrm{nmol} / 1(24 \cdot 8 \pm 7 \cdot 9 \mathrm{ng} / \mathrm{ml})) ; t=1 \cdot 7$; $\mathrm{DF}=17 ; \mathrm{NS}$ ).

Although the plasma nicotine concentrations produced by the gum and by smoking are similar on average, table I shows that the means conceal wide individual variation-five-fold for the smoking concentrations and 10-fold for the chewing gum. Furthermore, there was no relation whatsoever between the concentrations produced by the gum and those obtained by smoking $(r=-0.04$ for peaks and 0.14 for troughs). Neither was there any relation between an individual's peak plasma nicotine concentration after smoking and his usual cigarette consumption $(r=0.02)$ or even the number of cigarettes smoked on the day up to the time the blood sample was taken $(r=0.29$; NS). Similarly there was no significant relation between the number of pieces of gum used before the blood was taken and the plasma nicotine concentrations they produced $(r=0.31)$. In keeping with these findings there was only a small and statistically non-significant tendency for plasma nicotine concentrations to be higher in the subjects who attended in the later afternoon compared to those who came before lunch.

The low plasma nicotine concentration of subject No 21 when taking the gum may have been related to his great weight. Although the overall negative correlation between the subjects' weight and their nicotine concentrations on the gum did not reach significance in this study $(\mathrm{r}=-0.39 ; \mathrm{NS})$, the relationship was significant in a previous study $(\mathrm{r}=-0.56 ; \mathrm{n}=15 ; \mathrm{P}<0.05)$.

\section{PLASMA NICOTINE HALF LIFE AFTER SMOKING}

The decrease in plasma nicotine concentration from a mean peak of $194.2 \mathrm{nmol} / 1(31.5 \mathrm{ng} / \mathrm{ml})$ two minutes after a cigarette to the mean of $155.4 \mathrm{nmol} / \mathrm{l}(25.2 \mathrm{ng} / \mathrm{ml})$ after 25 minutes was rather less than expected even taking account of the tissue saturation with nicotine after a morning's smoking. Although accurate calculation is not possible from only two measurements, the overall average rate of decline suggests that the approximate average half life of nicotine in plasma under these conditions was just over one hour. Tissue saturation must have been complete by lunch time as the average peaktrough difference was $29.6 \mathrm{nmol} / \mathrm{l}(4.8 \mathrm{ng} / \mathrm{ml})$ before lunch compared with $43.8 \mathrm{nmol} / 1(7 \cdot 1 \mathrm{ng} / \mathrm{ml})$ later in the afternoon.

\section{CARBOXYHAEMOGLOBIN CONCENTRATIONS}

Average $\mathrm{COHb}$ concentrations when smoking were $8 \cdot 2 \%$ (SD 2.7) two minutes after a cigarette and $8.0 \%$ (SD 2.7) 25 minutes after. When subjects were chewing the gum and not smoking $\mathrm{COHb}$ averaged $1.9 \%($ SD 1.0 ) just before and $1.7 \%$ (SD 1.0 ) after 25 mins. In table I the two values for each day have been averaged as these data are of less interest and serve mainly to confirm that when taking the gum the subjects had largely avoided smoking. As expected, there was a positive correlation $(r=0.62 ; \mathrm{P}<0.005)$ between the $\mathrm{COHb} \%$ and plasma nicotine concentration two minutes after smoking. As with the plasma nicotine, there was no significant relation between the $\mathrm{COHb}$ concentration when smoking and the subjects' usual cigarette consumption $(r=0 \cdot 13 ; N S)$ or even the number of cigarettes smoked on the day $(r=0.39$; NS). The COHb concentration when taking gum and not smoking had an unexpected negative correlation with the peak nicotine level on the gum $(r=-0.65 ; P<0.002)$ and to a lesser degree with the trough nicotine level on the gum $(r=-0.40$; NS), possibly because those who got the lowest nicotine concentrations from the gum were more likely to sneak an odd cigarette.

\section{MISSING CIGARETTES}

Cigarettes were missed to a moderate degree by the group as a whole on the day when they were chewing the gum and not smoking. In response to the question "How much have you missed smoking cigarettes today ?" the average score was $46 \cdot 1$ on a linear scale, for which $0=$ not at all, $100=$ a lot. Nevertheless, there was considerable individual variation (SD 31.1). Six subjects missed their cigarettes very little (score <25), 10 missed them moderately (score 25-75), and five missed them a lot (score 75). The degree to which cigarettes were missed was related to usual cigarette consumption $(r=0.49$; $\mathrm{P}<0.05)$ but not to the plasma nicotine $(r=-0.23$; NS) or COHb concentrations $(r=0.05 ; \mathrm{NS})$ after smoking. Neither was there any relation between missing cigarettes and the ability of the gum to produce plasma nicotine levels comparable to smoking.

\section{SUBJECTIVE EFFECTS OF NICOTINE GUM}

Rating scale scores-There was wide individual variation in the ratings for taste, strength, and satisfaction. On average, the gum tasted bad rather than good (mean score 67.5 ) and tended to be too strong (mean 51.3), but it was moderately satisfying (mean $48 \cdot 6$ ). On scores ranging from $0-100$, subjects were categorised into three groups $<25,25-75, \quad 75$. Only two subjects rated the gum as tasting good $(<25)$, compared with nine intermediate and 10 for whom it tasted bad $(75)$. Seven subjects found the gum too strong $(>75)$, eight were intermediate, and six did not find it too strong. It was very satisfying $(<25)$ for six subjects, moderately satisfying for 11 , and in only four was it not at all satisfying. There was no association between the degree of satisfaction provided by the gum and the plasma nicotine concentrations it produced $(\mathrm{r}=-0.01$ for peaks; -0.22 for troughs; NS).

Side effects-Unwanted effects were common and occurred in all but four subjects. The incidence was twice as high as occurred in a previous clinical trial of $2-\mathrm{mg}$ nicotine gum (table II), which suggests that they are dose-related. Hiccups were disproportionately frequent on 4-mg compared to 2-mg gum. The seven subjects who had hiccups had higher peak nicotine concentrations than the other subjects while taking the gum but the difference was not significant on a two-tailed test (mean $217.6 \mathrm{nmol} / 1(35.3 \mathrm{ng} / \mathrm{ml})$ v $134.4 \mathrm{nmol} / 1(21.8 \mathrm{ng} / \mathrm{ml})$; $t=1.8 ; \mathrm{DF}=19 ; \mathrm{NS}$ ). Four of them (subjects $1,4,6,7)$ had higher nicotine concentrations on the gum than after smoking. There was not even a slight relation between plasma nicotine concentrations and any of the other side effects. One subject (No 2) with relatively high plasma nicotine concentrations on the gum felt faint and had to lie down before being transported home.

TABLE II-Number of subjects who had side effects when chewing 2-mg and 4-mg nicotine gum hourly

\begin{tabular}{l|c|c|c}
\hline \multicolumn{1}{c|}{ Side effect } & $\begin{array}{c}2 \mathrm{mg} \\
(\mathrm{N}=43)^{*}\end{array}$ & $\begin{array}{c}4 \mathrm{mg} \\
(\mathrm{N}=21)\end{array}$ & $\begin{array}{c}\text { Increased } \\
\text { incidence on } \\
\text { 4-mg gum }\end{array}$ \\
\hline $\begin{array}{l}\text { Sore mouth or throat } \\
\text { With ulceration }\end{array}$ & 11 & 12 & Two-fold \\
$\begin{array}{l}\text { Nausea } \\
\text { With vomiting }\end{array}$ & 12 & 11 & Two-fold \\
$\begin{array}{l}\text { Flatulence, indigestion, } \\
\text { epigastric discomfort }\end{array}$ & 7 & 2 & Two-fold \\
$\begin{array}{l}\text { Hiccups } \\
\text { Faintness or dizziness }\end{array}$ & 2 & 7 & Seven-fold \\
Laxative effect \\
$\begin{array}{l}\text { Tiredness of jaw } \\
\text { No side effects }\end{array}$ & 3 & 6 & Four-fold \\
& Not recorded & 5 & \\
\hline
\end{tabular}

*Subjects from a clinical trial reported previously.

Overall acceptability-Despite the unpleasant taste, local irritation, and other side effects all but three subjects took the gum as instructed. When asked, "Would you be able to go on chewing this amount of the gum for as long as two weeks ?" six subjects responded "No, I couldn't face it"; eight "Yes, with difficulty"; and seven "Yes, quite easily."

\section{Discussion}

The results show that chewing gum containing $4 \mathrm{mg}$ nicotine taken at a rate of one piece per hour produced plasma nicotine concentrations which were, on average, equivalent to those obtained during heavy cigarette smoking. In some cases the concentrations were two and even three times as high as with smoking. Out of 21 subjects only two could not, and one did not, take the gum as instructed. Apart from these, the average peak plasma nicotine concentration on the gum-175.7 nmol/1 (28.5 $\mathrm{ng} / \mathrm{ml}$ )-did not differ significantly from the average nicotine peak of $189.3 \mathrm{nmol} / 1(30.7 \mathrm{ng} / \mathrm{ml})$ just after a cigarette. Neither did the average trough level of $127.6 \mathrm{nmol} / 1(20.7 \mathrm{ng} / \mathrm{ml})$ just before starting the hourly gum, differ significantly from the mean of $152.9 \mathrm{nmol} / 1(24.8 \mathrm{ng} / \mathrm{ml}) 25$ minutes after completing a 
cigarette, and the difference would have been even less had the intervals after smoking $(25 \mathrm{~min})$ and completing the gum (30 min) been identical. The plasma nicotine concentrations produced by the 4-mg gum were approximately double the average of $66.0 \mathrm{nmol} / 1(10.7 \mathrm{ng} / \mathrm{ml})$ produced by $2-\mathrm{mg}$ nicotine gum in a previous study. ${ }^{4}$

Plasma nicotine concentrations varied widely between subjects both on the gum and when smoking. Peak concentrations when smoking varied from $72 \cdot 7-381 \cdot 6 \mathrm{nmol} / 1$ (11.8-61.9 $\mathrm{ng} / \mathrm{ml})$ compared to a range of $38 \cdot 8-500 \cdot 0 \mathrm{nmol} / 1(6 \cdot 3-81 \cdot 1 \mathrm{ng} / \mathrm{ml})$ on the gum. There was no correlation $(r=-0.04)$ between the nicotine concentrations obtained from smoking and from the gum. The variation in concentrations when smoking no doubt reflected individual differences in smoking pattern, whereas differences in absorption, metabolism, excretion, and the rate of chewing probably accounted for most of the variation when taking the gum, which was after all on a fixed schedule. It should be noted that urinary excretion was not controlled by acidification.

Though all but three subjects managed to chew the gum as instructed, few did not find it unpleasant. All but four experienced some unpleasant side effects and these were severe in eight subjects. Only two thought the gum tasted good. Apart from the unpleasant taste, local irritation to the mouth, throat, and stomach were common. Other effects such as nausea, hiccups, and faintness or dizziness were probably also due mainly to localised action of nicotine rather than to its systemic absorption, as those with low as well as high plasma nicotine concentrations were affected. Only in the case of hiccups was there an apparent relation to a high plasma nicotine concentration. All side effects were dose-related being twice as frequent in this study compared with a previous trial of $2-\mathrm{mg}$ nicotine gum. Hiccups, however, were seven times rather than twice as frequent on the 4-mg gum. Hiccups are not generally recognised as an effect of nicotine intoxication, ${ }^{10}$ possibly because they are peculiar to oral administration.

In this study subjects were attempting to adhere to a specified dose. For clinical use in cigarette withdrawal it may be more appropriate to take the gum only when necessary and this might reduce the incidence of side effects without jeopardising therapeutic efficacy. The fact that the gum is generally rather unpleasant may be an advantage serving to reduce the likelihood of prolonged dependence on the gum after successful cigarette withdrawal. It does, however, seem to be adequately tolerated for clinical purposes. Even on the fixed high-dose regimen of this trial there were only six subjects who felt they could not have continued taking it for two weeks.

Despite its unpleasant effects, the gum provided some satisfaction to all except four of the subjects, but the degree of this was not related to the plasma nicotine concentration it produced, suggesting that it was psychological rather than pharmacological. Similarly, on the day that subjects were chewing nicotine gum and not smoking, their psychological awareness of missing cigarettes was related to their usual cigarette consumption but not to pharmacological factors such as nicotine and carbon monoxide intake when smoking, nor to the degree to which the gum provided adequate nicotine substitution. Although the gum can probably provide adequate nicotine substitution it is not clear from this study that this contributes to its capacity to satisfy a deprived smoker or to reduce his sense of missing cigarettes.

The average decline in plasma nicotine concentration over 23 minutes from $194.2 \mathrm{nmol} / 1(31.5 \mathrm{ng} / \mathrm{ml})$ two minutes after a cigarette was only $38.8 \mathrm{nmol} / \mathrm{l}(6.3 \mathrm{ng} / \mathrm{ml})$. This suggests that the average half life of nicotine in the plasma of heavy smokers from midday onwards in a typical day's smoking is more than an hour. Previous estimates in regular smokers have been much shorter"less than $30 \mathrm{~min}$ " in one study of four smokers" $32 \mathrm{~min}$ in another study of four smokers. " Both these studies derived their estimates from the first cigarette of the day in smokers who had been deprived overnight; passage of nicotine from plasma into tissue would be greater under such conditions.

Our standardised sampling time of 25 minutes after completing a cigarette provides an arbitrary index of the natural trough levels just before a cigarette. Although most smokers allow a longer period between one cigarette and the next, the arbitrary 25 minutes would be fairly close to the average interval for a heavy-smoking sample such as this in which the average was 33 cigarettes per day. It is not known how far a drop in plasma nicotine concentration provides a cue to light up another cigarette. We have shown that there is some consistency in the peak plasma nicotine concentrations obtained by any one smoker at different times and on different days, ${ }^{13}$ but no studies have been made of the consistency of trough nicotine levels during natural smoking.

We conclude that 4-mg nicotine chewing gum can produce plasma nicotine concentrations equivalent to those obtained from smoking. The dosage required to achieve this varies widely among subjects. Flexible dosage according to the subjective needs of individual smokers would probably lower the incidence of side effects and might secure closer approximation to smoking concentrations of nicotine. In some cases the gum produced plasma nicotine concentrations two to three times as high as the subject had obtained from smoking, which suggests that it might be unduly hazardous to smokers with coronary heart disease. If used at all in such subjects plasma nicotine concentrations should probably be monitored. It is not clear from this study that any capacity the gum may have to act as a substitute for smoking is necessarily related to its capacity to provide nicotine.

We thank A B Leo and Co, Helsingborg, Sweden, for supplying the chewing gum, Jean Crutch for secretarial help, Colin Taylor for checking the statistics, and the Medical Research Council and Department of Health and Social Security for financial support. Dr Griffith Edwards, Dr M H Lader, and Dr R Kumar gave helpful comments and advice.

\section{References}

1 Ferno, O, Lichtneckert, S J A, and Lundgren, C E G, Psychopharmacologia, 1973, 31, 201.

2 Brantmark, B, Ohlin, P, and Westling, H, Psychopharmacologia, 1973, 31, 191.

${ }^{3}$ Russell, M A H, Feyerabend, C, and Cole, P V, British Medical fournal, $1976,1,1043$.

- Russell, M A H, et al, British Medical fournal, 1976, 2, 391.

Westling, H, Lakartidningen, 1976, 73, 2549.

${ }^{6}$ Russell, M A H, in Research Advances in Alcohol and Drug Problems, ed R J Gibbins et al, vol 3. New York, Wiley and Sons, 1976.

'Russell, M A H, Cole, P V, and Brown, E, Lancet, 1973, 1, 576.

* Feyerabend, C, Levitt, T, and Russell, M A H, Fournal of Pharmacy and Pharmacology, 1975, 27, 434.

${ }^{9}$ Russell, M A H, et al, British Medical fournal, 1973, 4, 512.

10 Volle, R L, and Koelle, G B, in The Pharmacological Basis of Therapeutics, ed L S Goodman and A Gilman, 5th edn, p 569. New York, MacMillan, 1975.

1 Isaac, P F, and Rand, M J, Nature, 1972, 236, 308

12 Armitage, A K, et al, British Medical fournal, 1975, 4, 313

13 Russell, M A H, et al, British Medical fournal, 1975, 2, 414.

(Accepted 25 February 1977) 